\title{
Bromopyrrole Alkaloids Isolated from the Patagonian Bryozoan Aspidostoma giganteum
}

\author{
Laura P. Patiño C, ${ }^{\dagger}$ Claudia Muniain, ${ }^{\dagger}$ Maria Elena Knott, ${ }^{\S}$ Lydia Puricelli, ${ }^{\S}$ and Jorge A. Palermo ${ }^{* \dagger}$ \\ ${ }^{\dagger}$ UMYMFOR, Departamento de Química Orgánica, Facultad de Ciencias Exactas y Naturales, Universidad de Buenos Aires, Ciudad \\ Universitaria, Pabellón 2 (1428), Buenos Aires, Argentina \\ ${ }^{\ddagger}$ CONICET, Laboratorio de Ecología Química y Biodiversidad Acuática, Instituto de Investigación e Ingeniería Ambiental, \\ Universidad de San Martín, Peatonal Belgrano 3563 (1650), San Martín, Buenos Aires, Argentina \\ ${ }^{\S}$ Research Area, “Angel H. Roffo” Institute of Oncology, University of Buenos Aires, Avenida San Martín 5481 (C1417DTB), Buenos \\ Aires, Argentina
}

\section{Supporting Information}

ABSTRACT: Nine new bromopyrrole alkaloids, aspidostomides $\mathrm{A}-\mathrm{H}$ and aspidazide $\mathrm{A}(1-9)$, were isolated from the Patagonian bryozoan Aspidostoma giganteum. Aspidostomides A-H have dibromotyrosine- or bromotryptophan-derived moieties forming either linear amides or pyrroloketopiperazine-type lactams with a bromopyrrole carboxylic acid as a common structural motif. On the other hand, aspidazide $A$ is a rare asymmetric acyl azide formed by an $\mathrm{N}-\mathrm{N}$ link of two different pyrroloketopiperazine lactams and is the first isolated compound of this class from marine invertebrates. This work is the first report of secondary metabolites isolated from a bryozoan from the Patagonian region. The structures of compounds 1-9 were elucidated by spectroscopic methods and chemical transformations. One of these compounds, aspidostomide E (5), was moderately active against the 786-O renal carcinoma cell line.

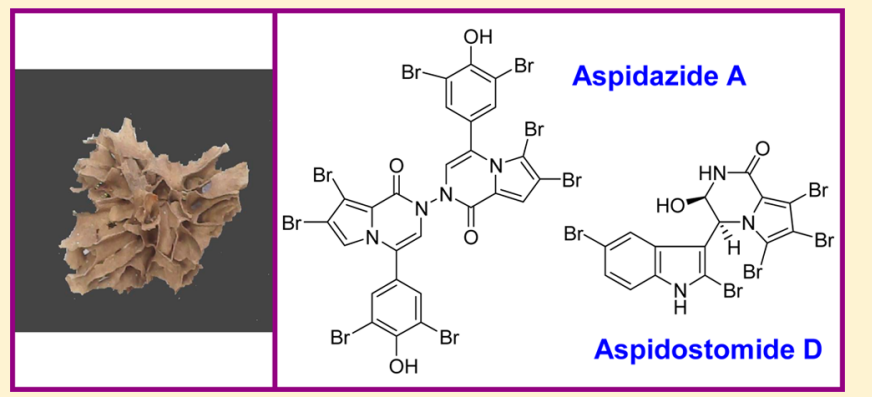

B ryozoans have emerged over the last decades as a source of biologically active and structurally diverse compounds, including a wide array of alkaloids. ${ }^{1-7}$ Many species belonging to the order Cheilostomata, especially from the Bugulidae and Flustridae families, have been the focus of extensive studies by chemists. These organisms have provided a great variety of secondary metabolites, among them the large family of the bryostatins ${ }^{8}$ from the Bugulidae family and the ubiquitous brominated physostigmine alkaloids from Flustridae. ${ }^{9-11}$ However, there are no previous reports of secondary metabolites from Aspidostomatidae bryozoans. In particular, the genus Aspidostoma comprises 27 species, and among them, Aspidostoma giganteum (Busk, 1854) has a wide distribution along the Magellanic and Antarctic regions, with records in Patagonia, Tierra del Fuego, Malvinas, and the South Shetland Islands. $^{12-14}$

As part of a research program on bioactive secondary metabolites from South Atlantic marine invertebrates, an investigation was conducted on the associated epibenthos that form the by-catch of commercial Patagonian fisheries. From an associated fauna sample, collected by trawling (60$100 \mathrm{~m}$ ) at the fishing grounds of the prawn Pleoticus muelleri (Bate, 1888) located in the Gulf of San Jorge (Patagonia, Argentina), two colonies of A. giganteum were obtained. A detailed analysis of their organic extract resulted in the isolation and structure elucidation of a series of bromopyrrole alkaloids derived from either bromotryptophan or bromotyrosine, aspidostomides $\mathrm{A}-\mathrm{H}(\mathbf{1 - 8})$, together with aspidazide $\mathrm{A}(\mathbf{9})$, and 9-O-ethyl aspidostomide $\mathrm{C}(\mathbf{1 0})$, which is probably an artifact, plus three brominated small aromatic compounds that are biosynthetically related to the above-mentioned substances. The structures of the isolated compounds were elucidated by HRMS, NMR techniques, and chemical transformations. One of these compounds, aspidostomide E (5), was moderately active against the 786-O renal carcinoma cell line. The present work is the first report on the chemistry of a bryozoan from the Patagonian region.

\section{RESULTS AND DISCUSSION}

The ethanolic extract of $A$. giganteum was fractionated by silica gel column chromatography, Sephadex LH20 permeation, and RP-18 HPLC. Further purification of the major components yielded pure compounds $\mathbf{1 - 1 0}$. Compound 1 was isolated as a light yellow, amorphous solid. HRESIMS of 1 showed an isotopic pattern corresponding to four bromine atoms, and a molecular formula of $\mathrm{C}_{13} \mathrm{H}_{9} \mathrm{Br}_{4} \mathrm{~N}_{2} \mathrm{O}_{3}$ was established, with eight degrees of unsaturation. The ${ }^{1} \mathrm{H}$ NMR spectrum of $\mathbf{1}$ (Table 1 ) showed eight signals, while the ${ }^{13} \mathrm{C}$ NMR spectrum had only 11 signals, which could indicate the presence of two pairs of

Received: January 6, 2014

Published: May 13, 2014 


\section{Chart 1}<smiles>[Z17]OC(CNC(=O)c1[nH]c([R2])c(Br)c1[R])c1cc(Br)c(O)c(Br)c1</smiles>

$\mathrm{R}_{1}=\mathrm{H}, \mathrm{R}_{2}=\mathrm{H}, \mathrm{R}_{3}=\mathrm{Br}$ : Aspidostomide $\mathrm{A}$ (1)

$\mathrm{R}_{1}=\mathrm{H}, \mathrm{R}_{2}=\mathrm{Br}, \mathrm{R}_{3}=\mathrm{H}$ : Aspidostomide $\mathrm{B}(\mathbf{2})$

$\mathrm{R}_{1}=\mathrm{H}, \mathrm{R}_{2}=\mathrm{Br}, \mathrm{R}_{3}=\mathrm{Br}$ : Aspidostomide C (3)

$\mathrm{R}_{1}=\mathrm{Et}, \mathrm{R}_{2}=\mathrm{Br}, \mathrm{R}_{3}=\mathrm{Br}$ : 9-O-Ethyl-aspidostomide $\mathrm{C}(\mathbf{1 0})$

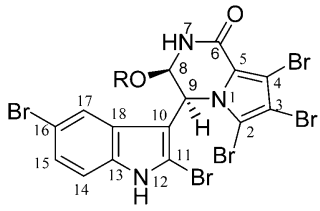

$\mathrm{R}=\mathrm{H}$ : Aspidostomide D (4)

$\mathrm{R}=\mathrm{CH}_{3}$ : Aspidostomide $\mathrm{E}(5)$

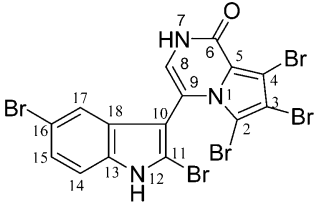

Aspidostomide $\mathrm{F}(\mathbf{6})$<smiles>COc1ccc(C(=O)C(NC(=O)c2cc(Br)c(Br)[nH]2)OC)cc1Br</smiles>

Aspidostomide $\mathrm{H}(\mathbf{8})$<smiles>O=C(NCCc1c(Br)[nH]c2cc(Br)cc(O)c12)c1cc(Br)c(Br)[nH]1</smiles>

Aspidostomide G (7)

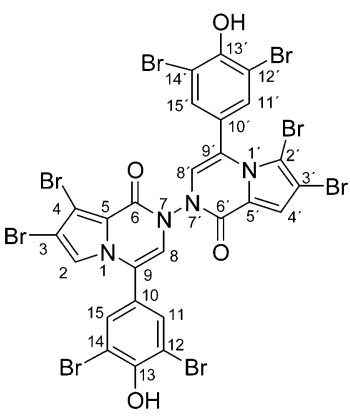

Aspidazide A (9)

Table 1. ${ }^{1} \mathrm{H}$ NMR Spectroscopic Data (500.13 $\left.\mathrm{MHz} \mathrm{CDCl}_{3},{ }^{a} \mathrm{CD}_{3} \mathrm{COCD}_{3}\right)$ of Compounds 1-3, 8, and 10

\begin{tabular}{|c|c|c|c|c|c|}
\hline position & $\mathbf{1}\left(\delta_{\mathrm{H}}, J\right.$ in $\left.\mathrm{Hz}\right)$ & $2\left(\delta_{\mathrm{H}}, J\right.$ in $\left.\mathrm{Hz}\right)$ & $3\left(\delta_{\mathrm{H}}, J\right.$ in $\left.\mathrm{Hz}\right)$ & $8\left(\delta_{\mathrm{H}}, J\right.$ in $\left.\mathrm{Hz}\right)$ & $10\left(\delta_{\mathrm{H}}, J\right.$ in $\left.\mathrm{Hz}\right)$ \\
\hline $\mathrm{NH}-1$ & 9.82, bs & 8.03 , bs & 10.10, bs & 10.10 , bs & 10.50, bs \\
\hline 2 & $7.01, \mathrm{~d}(3.3)$ & & & & \\
\hline 4 & & $6.96, \mathrm{~s}$ & & $6.86, \mathrm{~s}$ & \\
\hline NH-7 & 7.29, bt $(7.0)$ & 7.24, bt $(7.9)$ & 7.25 , bt $(6.0)$ & $7.31, \mathrm{~d}(8.7)$ & 7.35 , bdd $(7.0,3.5)$ \\
\hline \multirow[t]{2}{*}{8} & 3.82 , ddd $(14.0,7.0,3.4)$ & 3.62 , ddd $(14.0,7.9,5.0)$ & 3.87, ddd $(13.7,6.0,3.6)$ & $6.45, \mathrm{~d}(8.7)$ & 3.91, ddd $(14.0,7.0,3.9)$ \\
\hline & 3.54 , ddd $(14.0,7.4,3.5)$ & 3.43 , ddd $(14.0,7.5,4.8)$ & 3.56, ddd $(13.7,7.7,3.8)$ & & 3.34, ddd $(14.0,7.5,4.0)$ \\
\hline 9 & 4.86, dd $(7.4,3.4)$ & $4.85, \mathrm{dd}(7.5,5.0)$ & $4.89, \mathrm{dd}(7.7,3.6)$ & & $4.33, \mathrm{dd}(7.5,3.9)$ \\
\hline 11 & $7.52, \mathrm{~s}$ & $7.59, \mathrm{~d}(0.6)$ & $7.55, \mathrm{~s}$ & 8.08, dd $(8.7,2.1)$ & $7.45, \mathrm{~s}$ \\
\hline 14 & & & & $7.00, \mathrm{~d}(8.7)$ & \\
\hline 15 & $7.52, \mathrm{~s}$ & $7.59, \mathrm{~d}(0.6)$ & $7.55, \mathrm{~s}$ & $8.31, \mathrm{~d}(2.1)$ & $7.45, \mathrm{~s}$ \\
\hline $\mathrm{OH}$ & 5.93, bs & 5.85, bs & 5.94, bs & & 5.93, bs \\
\hline $\mathrm{C}-13 \mathrm{OCH}_{3}$ & & & & $4.02, \mathrm{~s}$ & \\
\hline $\mathrm{C}-8 \mathrm{OCH}_{3}$ & & & & $3.51, \mathrm{~s}$ & \\
\hline $\mathrm{O}-\mathrm{CH}_{2} \mathrm{CH}_{3}$ & & & & & $3.50,3.38(\mathrm{~m})$ \\
\hline $\mathrm{O}-\mathrm{CH}_{2}-\mathrm{CH}_{3}$ & & & & & $1.23, \mathrm{t}(7.0)$ \\
\hline
\end{tabular}

equivalent carbons. The presence of a $2 \mathrm{H}$ singlet at $\delta_{\mathrm{H}} 7.52$, which correlated (DEPT-HSQC) to an intense carbon signal at $\delta_{\mathrm{C}} 129.6$, strongly favored this assumption and suggested a possible symmetric aromatic ring. Nine of the ${ }^{13} \mathrm{C}$ signals corresponded to $\mathrm{sp}^{2}$ carbons, one of them $\left(\delta_{\mathrm{C}} 160.2\right)$ probably an amide carbonyl, while the two remaining signals belonged to an oxo-methine and a methylene. The presence of a second aromatic system was suggested by a doublet at $7.01 \mathrm{ppm}(J=$ $3.3 \mathrm{~Hz}, 1 \mathrm{H}$ ), which had a different set of HMBC correlations than the protons at $\delta_{\mathrm{H}}$ 7.52. The DEPT-HSQC spectrum indicated the presence of three exchangeable protons: two broad singlets at 9.82 and $5.93 \mathrm{ppm}$ and a broad triplet at 7.29 ppm. COSY correlations established a two-carbon side chain formed by the methylene ( 3.82 and $3.54 \mathrm{ppm})$ and the oxomethine at $4.86 \mathrm{ppm}\left(\delta_{\mathrm{C}} 72.2\right)$, which ended in an amide $\left(\delta_{\mathrm{H}}\right.$ $7.29, \mathrm{bt})$. HMBC correlations between the methylene protons and the amide carbonyl $\left(\delta_{\mathrm{C}} 160.2\right)$ confirmed this substructure. The equivalent aromatic protons at $\delta_{\mathrm{H}} 7.52$ had $\mathrm{HMBC}$ correlations with three quaternary aromatic carbons at 149.1, 136.2 , and $110.1 \mathrm{ppm}$. The relative intensity of the last signal suggested that this was the other duplicated carbon, while the signal at $\delta_{\mathrm{C}} 149.1$ was consistent with a phenolic moiety, thus accounting for the third oxygen atom required by the molecular formula. Taking into consideration the number of bromine atoms, this symmetric benzene ring is presumably derived from 3,5-dibromotyrosine, a frequent structural motif in many 
marine natural products. ${ }^{15}$ Comparison of the NMR values with literature data confirmed this assumption. ${ }^{16}$ An additional $\mathrm{HMBC}$ correlation of the aromatic protons at $\delta_{\mathrm{H}} 7.52$ with the oxo-methine indicated that the aliphatic side chain was linked to $\mathrm{C}-1$ of the aromatic ring (C-10). Up to this point, the remaining portion of the molecule to be assigned was an additional aromatic $\mathrm{C}_{4} \mathrm{H}_{2} \mathrm{Br}_{2} \mathrm{~N}$ system with three unsaturations, and a dibromopyrrole unit was the obvious choice. A COSY correlation between the pyrrole aromatic proton (7.01 ppm, $J=$ $3.3 \mathrm{~Hz}$ ) and the exchangeable proton at $9.82 \mathrm{ppm}$ established that the aromatic proton was vicinal to the pyrrole nitrogen, while an HMBC correlation between $\delta_{\mathrm{H}} 9.82$ and $\delta_{\mathrm{C}} 160.2$ linked the carbonyl to $\mathrm{C}-5$ of the pyrrole, and in this way C-3 and C-4 were assigned as the brominated positions on the pyrrole. The absolute configuration at the carbinolic position was determined as $R$ by the modified Mosher's method. ${ }^{17}$ In this way the structure of compound $\mathbf{1}$ was established as a 3,5dibromooctopamine derivative, for which the name aspidostomide A was coined. The numbering system adopted for this and the following compounds was based on the related bromopyrrole alkaloid oroidin.

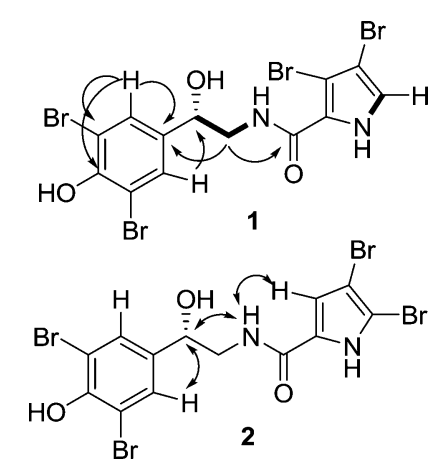

Figure 1. COSY (-) and HMBC correlations of 1 and NOESY correlations of 2 .

Aspidostomide B (2) had the same molecular formula $\left(\mathrm{C}_{13} \mathrm{H}_{10} \mathrm{Br}_{4} \mathrm{~N}_{2} \mathrm{O}_{3}\right)$ as aspidostomide $\mathrm{A}(1)$, and the only observable difference in the ${ }^{1} \mathrm{H}$ and ${ }^{13} \mathrm{C}$ NMR spectra corresponded to the pyrrole proton $\left(\delta_{\mathrm{H}} 6.96, \mathrm{~s}, \delta_{\mathrm{C}} 113.2\right)$, which in this case was a singlet. This multiplicity, together with the chemical shifts, suggested that this proton was located at either C-3 or C-4 of the pyrrole ring. An HMBC correlation with the amide carbonyl, as well as a NOESY correlation with the amide proton, placed the pyrrole proton at C-4. The remaining $2 \mathrm{D}$ NMR correlations confirmed that the backbones of compounds $\mathbf{1}$ and $\mathbf{2}$ were identical.

The molecular formula $\mathrm{C}_{13} \mathrm{H}_{9} \mathrm{Br}_{5} \mathrm{~N}_{2} \mathrm{O}_{3}$ was obtained by HRESIMS for aspidostomide $\mathrm{C}(\mathbf{3})$, and in this case an isotope pattern for five bromines was clearly observed. The absence in the ${ }^{1} \mathrm{H}$ NMR spectrum of the signal corresponding to the pyrrole proton, together with the replacement of a hydrogen atom by a bromine in the molecular formula compared with compounds $\mathbf{1}$ and 2, suggested the presence of a fully brominated pyrrole ring in 3 , which was confirmed by analysis of the 2D NMR spectra. The absolute configurations of compounds $\mathbf{2}$ and 3 were assumed to be the same as that of $\mathbf{1}$.

Aspidostomides $\mathrm{A}-\mathrm{C}$ were $\mathrm{C}_{13}$ compounds; however, the molecular formula $\mathrm{C}_{15} \mathrm{H}_{8} \mathrm{Br}_{5} \mathrm{~N}_{3} \mathrm{O}_{2}$ was obtained for compound 4, indicative of 11 degrees of unsaturation. Another distinctive feature of 4 was a different pattern in the ${ }^{1} \mathrm{H}$ NMR signals: a typical AMX aromatic system was evident $\left(\delta_{\mathrm{H}} 7.23, \mathrm{~d}, J=8.6\right.$ $\mathrm{Hz}, \delta_{\mathrm{H}} 7.12$, dd, $J=8.6,1.6 \mathrm{~Hz}$, and $\delta_{\mathrm{H}} 6.91$, bs), while the characteristic aliphatic system of compounds 1-3 was replaced by two broad ${ }^{1} \mathrm{H}$ singlets at 5.68 and $5.22 \mathrm{ppm}$ (Table 2).

Table 2. ${ }^{1} \mathrm{H}$ NMR Spectroscopic Data $(500.13 \mathrm{MHz}$; $\mathrm{CD}_{3} \mathrm{COCD}_{3}$ ) of Compounds 4-7

\begin{tabular}{|c|c|c|c|c|}
\hline position & $4 \underset{\mathrm{Hz})}{\left(\delta_{\mathrm{H}}, J \text { in }\right.}$ & $\begin{array}{c}5\left(\delta_{\mathrm{H}}, J \text { in }\right. \\
\mathrm{Hz})\end{array}$ & $6\left(\delta_{\mathrm{H}} J\right.$ in $\left.\mathrm{Hz}\right)$ & $7\left(\delta_{\mathrm{H}}, J\right.$ in $\left.\mathrm{Hz}\right)$ \\
\hline NH-1 4 & & & & 11.5 , bs 6.68 , s \\
\hline NH-7 & $7.68, \mathrm{~d}(4.5)$ & $8.18, \mathrm{~d}(5.1)$ & $10.1, \mathrm{~s}$ & $7.48, \mathrm{~s}$ \\
\hline 8 & 5.22, bd $(4.5)$ & $\begin{array}{l}\text { 4.96, dd (5.1, } \\
1.5)\end{array}$ & $6.79, \mathrm{bs}$ & $\begin{array}{l}3.50, \text { dd }(13.5, \\
6.7)\end{array}$ \\
\hline 9 & $5.68, \mathrm{bs}$ & 5.83, bd (1.5) & & $2.94, \mathrm{t}(6.7)$ \\
\hline $\mathrm{NH}-12$ & 11.5, bs & $11.50, \mathrm{bs}$ & $11.6, \mathrm{bs}$ & 10.55, bs \\
\hline 14 & $7.23, \mathrm{~d}(8.6)$ & $7.40, \mathrm{~d}(8.7)$ & $7.45, \mathrm{~d}(8.70)$ & $6.90, \mathrm{~d}(1.5)$ \\
\hline 15 & $\begin{array}{l}\text { 7.12, dd (8.6, } \\
1.6)\end{array}$ & $\begin{array}{l}\text { 7.28, dd (8.7, } \\
1.8)\end{array}$ & $\begin{array}{l}\text { 7.35, dd } \\
(8.70,1.8)\end{array}$ & \\
\hline 16 & & & & $6.53, \mathrm{~d}(1.5)$ \\
\hline 17 & $6.91, \mathrm{bs}$ & $7.01, \mathrm{~d}(1.8)$ & $7.70, \mathrm{~d}(1.75)$ & \\
\hline $\mathrm{OH}$ & & & & $9.11, \mathrm{bs}$ \\
\hline $\mathrm{OCH}_{3}$ & & $3.49, \mathrm{~s}$ & & \\
\hline
\end{tabular}

These two protons had HSQC correlations with ${ }^{13} \mathrm{C}$ signals at 59.8 and $78.1 \mathrm{ppm}$, respectively, clearly indicating that the latter corresponded to an oxidized position. On the other hand, the deshielding of the signal at $5.68 \mathrm{ppm}$ was probably explained by an $\mathrm{N}$-substitution in combination with anisotropic effects. Two exchangeable signals were also observed at $7.68(\mathrm{~d}, J=4.5 \mathrm{~Hz})$ and $11.5 \mathrm{ppm}$ (bs), and all these data gave the idea of a different core for compound 4 from that of 1-3. Sequential ${ }^{1} \mathrm{H}-{ }^{1} \mathrm{H}$ couplings were observed in the COSY spectrum between $\delta_{\mathrm{H}} 5.68, \delta_{\mathrm{H}} 5.22$, and the exchangeable signal at $\delta_{\mathrm{H}}$ 7.68 , which was assigned to an amide NH. An HMBC correlation between $\delta_{\mathrm{H}} 5.22$ and an amide carbonyl at $\delta_{\mathrm{C}} 156.8$ confirmed this substructure (Figure 2).

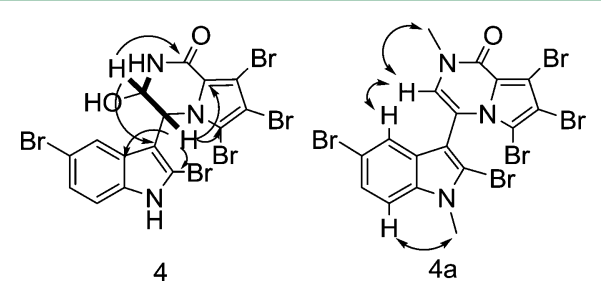

Figure 2. COSY (-) and HMBC correlations of 4 and NOESY correlations of $\mathbf{4 a}$.

By analysis of the HMBC correlations of the three aromatic protons in the AMX system, it was observed that all three correlated with the same two quaternary carbons (135.2 and $113.6 \mathrm{ppm}$ ). The proton corresponding to the ortho doublet at $7.23 \mathrm{ppm}$ had two additional correlations to other quaternary carbons (126.9 and $108.0 \mathrm{ppm}$ ). In particular the quaternary carbons at 126.9 and $135.2 \mathrm{ppm}$ had the typical chemical shifts of $\mathrm{C}-3 \mathrm{a}$ and $\mathrm{C}-7 \mathrm{a}$ positions in a C-3-substituted indole system. ${ }^{18}$ The exchangeable proton at $11.5 \mathrm{ppm}$ resembled a typical indole $\mathrm{NH}$, reinforcing this idea; however, no HMBC correlations were observed for this broad signal, which could confirm this hypothesis. As positions C-11 and C-16 (which correspond to C-2 and C-5 of the probable indole core) had to be substituted, two bromine atoms were assigned, out of the five bromines required by the molecular formula. In turn, the 
methine at $\delta_{\mathrm{H}} 5.68$ correlated in the $\mathrm{HMBC}$ spectrum with two quaternary carbons of the indole (C-11 and C-18) plus two additional quaternary carbons $\left(\delta_{\mathrm{C}} 123.6\right.$ and 107.9), which probably belonged to another aromatic system. A $\mathrm{C}_{4} \mathrm{Br}_{3} \mathrm{~N}$ fragment and four unsaturations still needed to be assigned. On the basis of the previously isolated aspidostomides, a tribromopyrrole structure was highly possible. The absence of the pyrrole $\mathrm{NH}$, together with the chemical shift of $\mathrm{C}-9$ and $\mathrm{H}$ $9\left(\delta_{\mathrm{C}} 59.8\right.$ and $\left.\delta_{\mathrm{H}} 5.68\right)$, strongly favored the closure of an additional ring between $\mathrm{C}-9$ and the pyrrole nitrogen, forming a bicyclic tribromopyrroloketopiperazine core, bound to C-10 (which corresponds to position 3 of an indole core), thus establishing the structure of compound 4, which was named aspidostomide D. Diagnostic NOESY correlations of $\mathrm{H}-17$ with H-8 and H-9 supported the proposed structure.

The structure of compound $\mathbf{4}$ was finally confirmed by chemical transformations. As no HMBC correlations were observed for the indole $\mathrm{NH}$, a methylation reaction was performed ( $\mathrm{NaH}$ and $\mathrm{MeI}$ in DMSO), to obtain the methylated derivative $4 a^{19}$ In the ${ }^{1} \mathrm{H}$ NMR spectrum of $4 \mathbf{a}$, two $N$-Me singlets $\left(\delta_{\mathrm{H}} 3.50, \delta_{\mathrm{C}} 35.0 ; \delta_{\mathrm{H}} 3.89, \delta_{\mathrm{C}} 32.3\right)$ were observed, indicating that both the lactam and the indole nitrogens were methylated. The absence of both $\mathrm{H}-8$ and $\mathrm{H}-9$ signals was also evident, being replaced by the formation of a new trisubstituted double bond. Analysis of the 2D NMR spectra of $4 a$ confirmed the formation of an enamide moiety by elimination of the C-8 hydroxy and $\mathrm{H}-9$. The $N$-methyl group at $\delta_{\mathrm{H}} 3.50$ showed an HMBC correlation to the enamide carbonyl $\left(\delta_{\mathrm{C}} 154.0\right)$ and a NOE correlation with the enamide proton $\left(\delta_{\mathrm{H}} 6.41\right)$, while an additional NOE correlation was observed between the enamide proton and $\mathrm{H}-17$. On the other hand, the $N$-methyl at $\delta_{\mathrm{H}} 3.89$ had an HMBC correlation with $\mathrm{C}-14$ (position 7 of the indole core) and a NOESY correlation with the ortho-coupled doublet at $7.28 \mathrm{ppm}$ (H-14), thus confirming the substitution by bromine at C-16. A detailed analysis of the $\mathrm{ms}^{2}$ spectrum on the quasimolecular ion $\mathrm{m} / z 659.6496$ (Supporting Information) also confirmed the proposed structure, since a main fragment ion was observed at $m / z 342.7742$, which may arise from the cleavage of the $\mathrm{C}-8-\mathrm{NH}$ and $\mathrm{C}-9-\mathrm{N}-1$ bonds.

The absolute configuration of $\mathbf{4}$ was determined by the modified Mosher's method with negative $\Delta \delta\left(\delta_{S}-\delta_{R}\right)$ values for $\mathrm{H}-14, \mathrm{H}-15$, and $\mathrm{H}-17$ and a positive $\Delta \delta$ value for the amide $\mathrm{N}-\mathrm{H}$. In this way, the absolute configuration of C-8 was established as $R$, while an $S$ configuration was deduced for C-9 based on the NOE correlation and small coupling constant between $\mathrm{H}-8$ and $\mathrm{H}-9$, which were cofacial on the lactam ring.

Compounds $\mathbf{5}$ and $\mathbf{6}$ were closely related to aspidostomide D. Compound 5, aspidostomide E, had a molecular formula of $\mathrm{C}_{16} \mathrm{H}_{9} \mathrm{Br}_{5} \mathrm{~N}_{3} \mathrm{O}_{2}$ obtained by HRESIMS. The major differences found in the ${ }^{1} \mathrm{H}$ and ${ }^{13} \mathrm{C}$ NMR spectra of compound 5 with respect to aspidostomide $\mathrm{D}$ (4) were the presence of signals corresponding to a methoxy group at $\delta_{\mathrm{H}} 3.49$ and $\delta_{\mathrm{C}} 54.2$, which correlated in the NOESY spectrum with H-8, H-9 (4.96 and $5.83 \mathrm{ppm})$ and the amide- $\mathrm{NH}(8.18 \mathrm{ppm})$, thus confirming that 5 was the $O$-methyl derivative of aspidostomide $\mathrm{D}$. On the other hand, aspidostomide $\mathrm{F}$ (6) had a molecular formula of $\mathrm{C}_{15} \mathrm{H}_{5} \mathrm{Br}_{5} \mathrm{~N}_{3} \mathrm{O}$ according to the HRESIMS. The ${ }^{1} \mathrm{H}$ and ${ }^{13} \mathrm{C}$ NMR spectra showed a signal corresponding to a vinyl proton at $\delta_{\mathrm{H}} 6.79, \delta_{\mathrm{C}} 119.6$ and that the signals that originally corresponded to $\mathrm{H}-8$ and $\mathrm{H}-9$ were no longer present. The chemical shifts of the vinyl proton and its associated carbon closely resembled those of the enamide obtained in derivative 4a. The presence of this enamide moiety was confirmed by an
HMBC correlation of this proton with the amide carbonyl. The structure of compound 6 was thus confirmed as the dehydro derivative of aspidostomide $\mathrm{D}$ (4).

A molecular formula of $\mathrm{C}_{15} \mathrm{H}_{11} \mathrm{Br}_{4} \mathrm{~N}_{3} \mathrm{O}_{2}$ was obtained for aspidostomide $\mathrm{G}$ (7). The ${ }^{1} \mathrm{H}$ NMR spectrum showed nine signals, four of them corresponding to exchangeable protons at 7.48, 9.11, 10.55, and $11.50 \mathrm{ppm}$ as observed in the HSQC spectrum. The five remaining signals belonged to a pair of methylene groups (2.94 and $3.50 \mathrm{ppm}$ ) and three aromatic protons, two of which were meta-coupled $\left[\delta_{\mathrm{H}} 6.53(\mathrm{~d}, J=1.5\right.$ $\mathrm{Hz}), \delta_{\mathrm{H}} 6.68(\mathrm{bs})$, and $\left.\delta_{\mathrm{H}} 6.90(\mathrm{~d}, J=1.5 \mathrm{~Hz})\right]$. Both metacoupled protons correlated in the HMBC spectrum with the same three quaternary carbons (151.2, 116.2, and $114.9 \mathrm{ppm})$ (Figure 3). The signal at $\delta_{\mathrm{H}} 6.53$ showed an NOE correlation

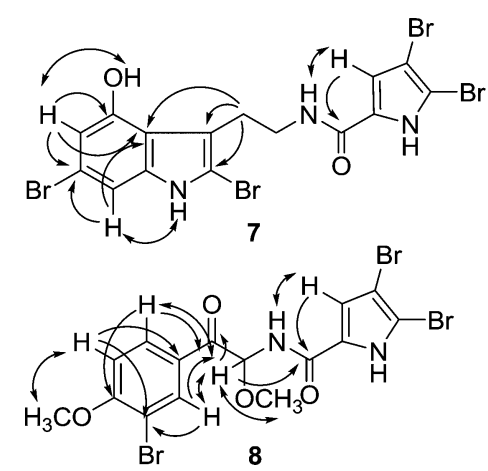

Figure 3. HMBC and NOESY correlations of compounds 7 and 8.

with $\delta_{\mathrm{H}} 9.11$, while $\delta_{\mathrm{H}} 6.90$ had a NOE with $\delta_{\mathrm{H}} 10.55$. These correlations were indicative of an indole ring with a hydroxy group at C-4. The methylene at $2.94 \mathrm{ppm}$ showed correlations in the $\mathrm{HMBC}$ spectrum not only with the other methylene (3.50 ppm) but also with C-3, C-2, and C-3a of the indole core. All of these data indicated substitution by the methylene chain at C-10 (C-3 of the indole core). Once again, the presence of a carbonyl carbon at $159.1 \mathrm{ppm}$ and the $\mathrm{NH}$ signal at $7.48 \mathrm{ppm}$ were typical of an amide group. This amide was $\mathrm{N}$-bonded to the alkyl chain connected to the indole group and also to a dibromo pyrrole ring. The presence of a singlet at $\delta_{\mathrm{H}} 6.68$ that had HMBC correlations with $\mathrm{C}-5$ and $\mathrm{C}-3$ and an NOE correlation with the amide $\mathrm{NH}$ clearly identified the pyrrole proton as $\mathrm{H}-4$.

Compound $\mathbf{8}$ (aspidostomide $\mathrm{H}$ ) had a molecular formula of $\mathrm{C}_{15} \mathrm{H}_{13} \mathrm{Br}_{3} \mathrm{~N}_{2} \mathrm{O}_{4}$, indicative of nine degrees of unsaturation. The ${ }^{13} \mathrm{C}$ NMR spectrum of $\mathbf{8}$ showed signals corresponding to two carbonyl carbons: an amide (160.7 ppm) and a conjugated ketone $(189.4 \mathrm{ppm})$. This was the first compound of the series to present a ketone in its structure. In the ${ }^{1} \mathrm{H}$ NMR spectrum some characteristic fragments could be identified: an AMX aromatic system $\left[\delta_{\mathrm{H}} 8.31(\mathrm{~d}, J=2.1 \mathrm{~Hz}), \delta_{\mathrm{H}} 8.08(\mathrm{dd}, J=8.7\right.$, $2.1 \mathrm{~Hz})$, and $\left.\delta_{\mathrm{H}} 7.00(\mathrm{~d}, J=8.7 \mathrm{~Hz})\right]$, two methoxy groups at 3.51 and $4.02 \mathrm{ppm}$, together with two exchangeable protons $\left(\delta_{\mathrm{H}} 7.31\right.$, probably an amide, and $\left.\delta_{\mathrm{H}} 10.10 \mathrm{ppm}\right)$. Two additional methine signals were also observed: one of them $\left(\delta_{\mathrm{H}}\right.$ $\left.6.45, \delta_{\mathrm{C}} 77.6\right)$ was clearly an oxomethine, while the other $\left(\delta_{\mathrm{H}}\right.$ $\left.6.86, \delta_{\mathrm{C}} 113.7\right)$ probably belonged to a bromopyrrole. Analysis of the COSY spectrum showed a correlation between the amide proton at $7.31 \mathrm{ppm}$ and the oxomethine at $6.45 \mathrm{ppm}$. This in turn had HMBC correlations with the two carbonyls and with a methoxy group $\left(\delta_{\mathrm{H}} 3.51\right)$. In this way, it was clear that the oxomethine (C-8) had a methoxy substituent and was located 
Table 3. ${ }^{13} \mathrm{C}$ NMR Spectroscopic Data (125.13 $\left.\mathrm{MHz} ; \mathrm{CDCl}_{3}\right)$ of Compounds $1-3$, 8, and 10

\begin{tabular}{|c|c|c|c|c|c|}
\hline position & $\mathbf{1}\left(\delta_{\mathrm{C}}\right)$ & $2\left(\delta_{\mathrm{C}}\right)$ & $3\left(\delta_{\mathrm{C}}\right)$ & $8\left(\delta_{\mathrm{C}}\right)$ & $10\left(\delta_{\mathrm{C}}\right)$ \\
\hline 2 & 121.3, $\mathrm{CH}$ & 104.0, C & 105.6, C & 106.8, C & $105.4, \mathrm{C}$ \\
\hline 3 & 100.6, C & 98.6, C & $100.5, \mathrm{C}$ & $100.4, \mathrm{C}$ & $100.1, \mathrm{C}$ \\
\hline 4 & 101.5, C & 113.2, $\mathrm{CH}$ & 104.1, C & 113.7, $\mathrm{CH}$ & 103.8, C \\
\hline 5 & $122.9, \mathrm{C}$ & $128.3, \mathrm{C}$ & 124.2, C & 125.9, C & 124.6, C \\
\hline 6 & $160.2, \mathrm{C}$ & $160.1, \mathrm{C}$ & 159.3, C & $159.6, \mathrm{C}$ & 158.2, C \\
\hline 8 & $47.5, \mathrm{CH}_{2}$ & 47.4, $\mathrm{CH}_{2}$ & 47.3, $\mathrm{CH}_{2}$ & 77.9, $\mathrm{CH}$ & 45.7, $\mathrm{CH}_{2}$ \\
\hline 9 & $72.2, \mathrm{CH}$ & $70.9, \mathrm{CH}$ & 72.0, $\mathrm{CH}$ & 189.4, C & $78.8, \mathrm{CH}$ \\
\hline 10 & 136.2, C & 137.9, C & 136.0, C & 127.4, C & $134.2, \mathrm{C}$ \\
\hline 11 & 129.6, CH & 130.0, CH & 129.5, CH & 134.9, $\mathrm{CH}$ & 130.1, CH \\
\hline 12 & 110.1, C & $110.4, \mathrm{C}$ & 110.0, C & 112.4, C & $110.2, \mathrm{C}$ \\
\hline 13 & 149.1, C & $149.5, \mathrm{C}$ & $149.1, \mathrm{C}$ & 160.7, C & 149.2, C \\
\hline 14 & 110.1, C & $110.4, \mathrm{C}$ & 110.0, C & 111.3, $\mathrm{CH}$ & $110.2, \mathrm{C}$ \\
\hline 15 & 129.6, CH & 130.0, CH & 129.5, CH & $130.9, \mathrm{CH}$ & 130.1, CH \\
\hline $\mathrm{C}-13 \mathrm{OCH}_{3}$ & & & & 56.6, $\mathrm{CH}_{3}$ & \\
\hline $\mathrm{C}-8 \mathrm{OCH}_{3}$ & & & & $55.3, \mathrm{CH}_{3}$ & \\
\hline $\mathrm{O}-\underline{\mathrm{CH}_{2}} \mathrm{CH}_{3}$ & & & & & 65.0, $\mathrm{CH}_{2}$ \\
\hline $\mathrm{O}-\mathrm{CH}_{2}-\mathrm{CH}_{3}$ & & & & & $15.3, \mathrm{CH}_{3}$ \\
\hline
\end{tabular}

between the ketone (C-9) and amide groups, which explained its high $\delta_{\mathrm{H}}$. As for the aromatic AMX system, two of these protons were heavily deshielded and showed HMBC correlations with the ketone group. This could be explained if the ketone was conjugated with a 3,4-disubstituted aromatic ring. Both deshielded protons showed HMBC correlations with a quaternary carbon at $\delta_{\mathrm{C}} 160.7$, which in turn correlated with the additional methoxy group $\left(\delta_{\mathrm{H}} 4.02\right)$. These data determined the nature of the substituents on the benzene ring: a methoxy at position 4 and a bromine at position 3 of the aromatic ring (C-13 and $\mathrm{C}-12$, respectively). NOE correlations between the methoxy at $\delta_{\mathrm{H}} 4.02$ and the aromatic proton at $\delta_{\mathrm{H}}$ 7.00 (H-14), H-8 and $\mathrm{H}-11$, and $\mathrm{H}-8$ and $\mathrm{H}-15$ confirmed this partial substructure. As in the previous compounds, the portion of the molecule that remained to be identified corresponded to a dibromopyrrole carboxylic acid. The chemical shifts of the pyrrole proton and its associated carbon $\left(\delta_{\mathrm{H}} 6.86 ; \delta_{\mathrm{C}} 113.7\right)$, its multiplicity (singlet), and a diagnostic NOE with the amide $\mathrm{NH}\left(\delta_{\mathrm{H}} 7.31\right)$ placed the pyrrole proton at C-4, finally establishing the gross structure of aspidostomide $\mathrm{H}(8)$. The absolute configuration at $\mathrm{C}-8$ could not be determined in this case due to a lack of sample.

The last new compound of this series (9) showed two symmetric clusters in the negative mode HRESIMS spectrum, which corresponded to polybrominated ions $(\mathrm{m} / z 1072.4232$ $[\mathrm{M}-\mathrm{H}]^{-}$and $\left.m / z 1094.4100[\mathrm{M}-2 \mathrm{H}+\mathrm{Na}]^{-}\right)$, giving rise to a molecular formula of $\mathrm{C}_{26} \mathrm{H}_{10} \mathrm{Br}_{8} \mathrm{~N}_{4} \mathrm{O}_{4}$ with 20 degrees of unsaturation. This molecular formula was especially interesting, as aspidostomides $\mathrm{A}-\mathrm{C}$ were $\mathrm{C}_{13}$ compounds, suggesting that compound 9 could be a dimeric structure formed by the union of two $\mathrm{C}_{13} \mathrm{H}_{5} \mathrm{Br}_{4} \mathrm{~N}_{2} \mathrm{O}_{2}$ monomers. In the negative mode mass spectrum, an additional ion was observed at $\mathrm{m} / \mathrm{z} 536.7130$, which corresponded to the formula $\mathrm{C}_{13} \mathrm{H}_{5} \mathrm{Br}_{4} \mathrm{~N}_{2} \mathrm{O}_{2}$. The ${ }^{1} \mathrm{H}$ NMR spectrum of 9 showed only six downfield singlets $\left[\delta_{\mathrm{H}}\right.$ $7.61(\mathrm{~s}, 2 \mathrm{H}), 7.60(\mathrm{~s}, 2 \mathrm{H}), 7.12(\mathrm{~s}, 1 \mathrm{H}), 6.58(\mathrm{~s}, 1 \mathrm{H}), 6.53(\mathrm{~s}$, $1 \mathrm{H})$, and $6.47(\mathrm{~s}, 1 \mathrm{H})]$, while, in the 2D NMR spectra, two sets of paired signals could be clearly detected. Inspection of the ${ }^{13} \mathrm{C}$ NMR spectrum confirmed the presence of paired signals of similar chemical shifts, indicative of either a dimeric structure or the presence of two unresolved very similar compounds (Table 5). In particular the proton signals at 7.61 and $7.60 \mathrm{ppm}(2 \mathrm{H}$ each) had similar sets of COSY and HMBC correlations, which
Table 4. ${ }^{13} \mathrm{C}$ NMR Spectroscopic Data (125.13 MHz; $\mathrm{CD}_{3} \mathrm{COCD}_{3}$ ) of Compounds 4-7

\begin{tabular}{llllc} 
position & $4\left(\delta_{\mathrm{C}}\right)$ & $5\left(\delta_{\mathrm{C}}\right)$ & $\boldsymbol{6}\left(\delta_{\mathrm{C}}\right)$ & $7\left(\delta_{\mathrm{C}}\right)$ \\
2 & $107.9, \mathrm{C}$ & $108.0, \mathrm{C}$ & $109.5, \mathrm{C}$ & $103.9, \mathrm{C}$ \\
3 & $104.5, \mathrm{C}$ & $104.5, \mathrm{C}$ & $101.1, \mathrm{C}$ & $98.5, \mathrm{C}$ \\
4 & $102.7, \mathrm{C}$ & $103.0, \mathrm{C}$ & $100.9, \mathrm{C}$ & $112.0, \mathrm{CH}$ \\
5 & $123.6, \mathrm{C}$ & $123.4, \mathrm{C}$ & $123.2, \mathrm{C}$ & $128.7, \mathrm{C}$ \\
6 & $156.8, \mathrm{C}$ & $156.6, \mathrm{C}$ & $150.4, \mathrm{C}$ & $159.1, \mathrm{C}$ \\
8 & $78.1, \mathrm{CH}$ & $85.0, \mathrm{CH}$ & $119.6, \mathrm{CH}$ & $40.2, \mathrm{CH}_{2}$ \\
9 & $59.8, \mathrm{CH}$ & $58.0, \mathrm{CH}$ & $123.8, \mathrm{C}$ & $25.8, \mathrm{CH}_{2}$ \\
10 & $108.0, \mathrm{C}$ & $107.5, \mathrm{C}$ & $106.4, \mathrm{C}$ & $112.4, \mathrm{C}$ \\
11 & $110.7, \mathrm{C}$ & $111.0, \mathrm{C}$ & $110.6, \mathrm{C}$ & $107.7, \mathrm{C}$ \\
13 & $135.2, \mathrm{C}$ & $135.3, \mathrm{C}$ & $134.8, \mathrm{C}$ & $138.9, \mathrm{C}$ \\
14 & $113.1, \mathrm{CH}$ & $113.1, \mathrm{CH}$ & $113.0, \mathrm{CH}$ & $105.8, \mathrm{CH}$ \\
15 & $125.2, \mathrm{CH}$ & $125.3, \mathrm{CH}$ & $125.4, \mathrm{CH}$ & $114.9, \mathrm{C}$ \\
16 & $113.6, \mathrm{C}$ & $113.7, \mathrm{C}$ & $113.8, \mathrm{C}$ & $107.9, \mathrm{CH}$ \\
17 & $119.7, \mathrm{CH}$ & $119.7, \mathrm{CH}$ & $121.1, \mathrm{CH}$ & $151.2, \mathrm{C}$ \\
18 & $126.9, \mathrm{C}$ & $126.8, \mathrm{C}$ & $131.9, \mathrm{C}$ & $116.2, \mathrm{C}$ \\
$\mathrm{O}-\mathrm{CH}_{3}$ & & $54.2, \mathrm{CH}$ & & \\
\hline
\end{tabular}

clearly resembled the characteristic 3,5-dibromo-4-hydroxyphenyl moieties typical of compounds $1-3$. The singlet at $\delta_{\mathrm{H}}$ $7.61(\mathrm{H}-11 / \mathrm{H}-15)$ correlated to $\mathrm{C}-13\left(\delta_{\mathrm{C}} 151.6\right), \mathrm{C}-9\left(\delta_{\mathrm{C}}\right.$ $125.6), \mathrm{C}-10\left(\delta_{\mathrm{C}} 117.3\right)$, and $\mathrm{C}-12 / \mathrm{C}-14\left(\delta_{\mathrm{C}} 109.6\right)$, while the signal at $\delta_{\mathrm{H}} 7.60\left(\mathrm{H}-11^{\prime} / \mathrm{H}-15^{\prime}\right)$ showed correlations with $\mathrm{C}$ $13^{\prime}\left(\delta_{\mathrm{C}} 151.7\right), \mathrm{C}-10^{\prime}\left(\delta_{\mathrm{C}} 117.0\right), \mathrm{C}-9^{\prime}\left(\delta_{\mathrm{C}} 125.8\right)$, and C-12' $\mathrm{C}-14^{\prime}\left(\delta_{\mathrm{C}} 109.7\right)$. A similar trend was evident with the protons at $\delta_{\mathrm{H}} 6.47$ and 6.53 , which also had similar HMBC subspectra. Both protons correlated to the corresponding C-10 of their respective substructures and with an amide carbonyl. These correlations resembled those observed for the enamide moiety in aspidostomide $F(6)$, except that in compound 6 the pyrroloketopiperazine ring was connected to an indole, and in this case each enamide seemed to be connected to a different 3,5-dibromo-4-hydroxyphenyl group. The two remaining proton singlets at $\delta_{\mathrm{H}} 7.12$ and 6.58 showed HMBC correlations consistent with bromopyrrole substructures. The difference in chemical shift could be explained in terms of different substitution patterns on the pyrrole rings. An intriguing fact was that, although two distinct amide carbonyls were present in the molecule, no amide protons could be detected. In the 
Table 5. NMR Spectroscopic Data of Aspidazide A (9) (500.13 MHz for ${ }^{1} \mathrm{H}, 125.13 \mathrm{MHz}$ for ${ }^{13} \mathrm{C}$; $\mathrm{CD}_{3} \mathrm{COCD}_{3}$ )

\begin{tabular}{|c|c|c|}
\hline position & $\delta_{\mathrm{H}}$ & $\delta_{\mathrm{C}}$, type \\
\hline 2 & $119.9, \mathrm{CH}$ & $6.58, \mathrm{~s}$ \\
\hline 3 & $100.0, \mathrm{C}$ & \\
\hline 4 & 105.7, C & \\
\hline 5 & 123.3, C & \\
\hline 6 & $154.3, \mathrm{C}$ & \\
\hline 8 & 116.9, $\mathrm{CH}$ & $6.53, \mathrm{~s}$ \\
\hline 9 & 125.6, C & \\
\hline 10 & 117.3, C & \\
\hline 11 & 135.4, CH & $7.61, \mathrm{~s}$ \\
\hline 12 & 109.6, C & \\
\hline 13 & 151.6, C & \\
\hline 14 & $109.6, \mathrm{C}$ & \\
\hline 15 & 135.4, $\mathrm{CH}$ & $7.61, \mathrm{~s}$ \\
\hline $2^{\prime}$ & $99.4, \mathrm{C}$ & \\
\hline $3^{\prime}$ & 101.5, C & \\
\hline $4^{\prime}$ & 112.6, $\mathrm{CH}$ & $7.12, \mathrm{~s}$ \\
\hline $5^{\prime}$ & $127.5, \mathrm{C}$ & \\
\hline $6^{\prime}$ & $153.7, \mathrm{C}$ & \\
\hline $8^{\prime}$ & 117.4, $\mathrm{CH}$ & $6.47, \mathrm{~s}$ \\
\hline $9^{\prime}$ & $125.8, \mathrm{C}$ & \\
\hline $10^{\prime}$ & $117.0, \mathrm{C}$ & \\
\hline $11^{\prime}$ & 135.3, $\mathrm{CH}$ & $7.60, \mathrm{~s}$ \\
\hline $12^{\prime}$ & 109.7, C & \\
\hline $13^{\prime}$ & 151.7, C & \\
\hline $14^{\prime}$ & 109.7, C & \\
\hline $15^{\prime}$ & $135.3, \mathrm{CH}$ & $7.60, \mathrm{~s}$ \\
\hline
\end{tabular}

previously isolated compounds, the amide $\mathrm{NH}$ protons were always clearly observed. The fact that both enamide vinylic protons were singlets was consistent with the absence of both amide protons. The only major difference in the $2 \mathrm{D}$ NMR spectra of the two substructures was observed precisely in the NOESY correlations of the enamide $\mathrm{sp}^{2}$ protons at 6.53 and $6.47 \mathrm{ppm}$. Each enamide proton correlated to its respective aromatic two-proton singlet of the corresponding 3,5-dibromo4-hydroxyphenyl group $\left(\delta_{\mathrm{H}} 7.61 ; 6.53 ; \delta_{\mathrm{H}} 7.60 ; 6.47\right)$, while $\delta_{\mathrm{H}}$ 6.47 had an additional NOE with the pyrrole proton at $\delta_{\mathrm{H}} 6.58$. In turn, both $\mathrm{sp}^{2}$ enamide protons correlated with each other, and no additional NOESY correlations were observed for $\delta_{\mathrm{H}}$
6.53. On the other hand, the aromatic protons at $\delta_{\mathrm{H}} 7.61$ correlated with both pyrrole protons. From the evidence gathered so far, especially the NOE correlations between protons of the different parts of the molecule, it was clear that there was some kind of symmetry in the dimeric structure, which was only broken by the different substitution in the pyrrole rings. At this point, the possibility of a mixture of unresolved isomers was less probable.

All the facts gathered so far suggested a possible $\mathrm{N}-\mathrm{N}$ link between the two lactams, giving rise to an asymmetrical diacylazide, a functional group that had been reported previously in a few natural products, but is extremely rare. Because no suitable crystals for X-ray diffraction could be obtained, the final confirmation of the proposed structure was obtained by chemical transformations (Figure 4). Methylation of compound 9 under basic conditions ( $\mathrm{NaH}, \mathrm{MeI}$ in DMSO) yielded two products, $\mathbf{9 a}$ and $\mathbf{9 b}$, which were purified by preparative TLC. The ${ }^{1} \mathrm{H}$ NMR spectrum of compound 9a showed five singlets $\left[\delta_{\mathrm{H}} 7.83(\mathrm{H}-11\right.$ and $\mathrm{H}-15), \delta_{\mathrm{H}} 6.80(\mathrm{H}-8)$, $\delta_{\mathrm{H}} 6.74(\mathrm{H}-2), \delta_{\mathrm{H}} 3.95\left(\delta_{\mathrm{C}} 60.4, O-\mathrm{CH}_{3}\right)$, and $\delta_{\mathrm{H}} 3.43\left(\delta_{\mathrm{C}} 33.5\right.$, $\left.N-\mathrm{CH}_{3}\right)$, while compound $9 \mathbf{b}$ had a similar set of signals $\left[\delta_{\mathrm{H}}\right.$ $7.85\left(\mathrm{H}-11^{\prime}\right.$ and $\left.\mathrm{H}-15^{\prime}\right), \delta_{\mathrm{H}} 6.85\left(\mathrm{H}-8^{\prime}\right), \delta_{\mathrm{H}} 7.24\left(\mathrm{H}-4^{\prime}\right), \delta_{\mathrm{H}}$ $3.96\left(\delta_{\mathrm{C}} 60.4, \mathrm{O}-\mathrm{CH}_{3}\right)$, and $\left.\delta_{\mathrm{H}} 3.49\left(\delta_{\mathrm{C}} 33.8, N-\mathrm{CH}_{3}\right)\right]$. It was evident that the diacylazide bond was cleaved by a hydride reduction, followed by $\mathrm{N}$-methylation, together with $\mathrm{O}$ methylation of the phenolic groups. This $\mathrm{N}-\mathrm{N}$ cleavage was no surprise, since it is well known that hydrazo and azo compounds are easily cleaved by a variety of reducing agents. ${ }^{20}$ $\mathrm{NaH}$ is not frequently used as a reducing agent due to its basicity; however, it has been reported that it can easily reduce $\mathrm{S}-\mathrm{S}, \mathrm{Si}-\mathrm{Si}$, and $\mathrm{Si}-\mathrm{Cl}$ bonds. ${ }^{21}$ In fact, a well-known method for the reduction of disulfide bridges in proteins makes use of $\mathrm{NaH}$ in DMSO. ${ }^{22}$ This dual character of $\mathrm{NaH}$ as a base or hydride donor has been studied. ${ }^{23 a, b}$ In this case, the cleavage of the easily reduced $\mathrm{N}-\mathrm{N}$ bond was a bonus that helped with the structure elucidation. Correlations observed in the NOESY spectra confirmed the assignment of the methyl groups and the substructures that formed compound 9: in the case of 9a, NOE correlations were observed between the N-Me $\left(\delta_{\mathrm{H}} 3.43\right)$ and the enamide double-bond proton $\left(\delta_{\mathrm{H}} 6.80\right)$, between the latter and the phenyl ring protons $\left(\delta_{\mathrm{H}} 7.83\right)$, and between the phenyl ring protons and the pyrrole proton $\left(\delta_{\mathrm{H}} 6.74\right)$. These data confirmed that in this substructure the pyrrole proton was<smiles>O=c1c2c(Br)c(Br)cn2c(-c2cc(Br)c(O)c(Br)c2)cn1-n1cc(-c2cc(Br)c(O)c(Br)c2)n2c(Br)c(Br)cc2c1=O</smiles><smiles>COc1c(Br)cc(-c2cn(C)c(=O)c3c(Br)c(Br)cn23)cc1Br</smiles><smiles>COc1c(Br)cc(-c2cn(C)c(=O)c3cc(Br)c(Br)n23)cc1Br</smiles><smiles>COc1ccc(-c2c[nH]c(=O)c3c(Br)c(Br)cn23)cc1Br</smiles><smiles>O=c1[nH]cc(-c2cc(Br)c(O)c(Br)c2)n2c(Br)c(Br)cc12</smiles>

Figure 4. Chemical transformations of compound 9. 
vicinal to the nitrogen. On the other hand, compound $9 \mathrm{~b}$ displayed NOE correlations only between $\delta_{\mathrm{H}} 3.49$ and 6.85 and between $\delta_{\mathrm{H}} 6.85$ and 7.85. In order to rule out definitively the possibility of two unresolved compounds for 9, the previous reaction was repeated without addition of MeI. In the case of two unresolved compounds no change would be expected. However, once again two compounds were formed, in this case 9c and 9d, which were purified by preparative TLC and characterized by NMR and HRMS. Both products preserved the ${ }^{1} \mathrm{H}$ NMR signals corresponding to their respective portion of compound 9 , but in this case, the $\mathrm{NH}$ protons of the lactams were clearly observable, coupled to their corresponding enamide $\mathrm{sp}^{2}$ protons. This was the definitive proof of the asymmetrical diacylazide structure of compound 9 , which was named aspidazide A.

Aspidostomides A-C are structurally related to the dibromotyrosine-derived compounds that are typical in sponges of the order Verongida, such as the agelasins and fistularins, and especially to hemifistularin-3, which is also a dibromooctopamine derivative. ${ }^{24}$ However, to the best of our knowledge, compounds of this type have not been previously isolated from bryozoans. The same can be said for aspidostomides D-F, which are brominated pyrroloketopiperazine alkaloids very similar to a series of compounds typically isolated from sponges of the Agelasidae and Axinellidae families, such as the longamides, ${ }^{25}$ agelastatins, ${ }^{26 a, b}$ mukanadin $\mathrm{C},{ }^{27}$ hanishin, ${ }^{28}$ cyclooroidin, ${ }^{29}$ and the agesamides. ${ }^{30}$ As in other cases in which compounds of great structural similarity have been isolated from taxonomically unrelated marine invertebrates belonging to different phyla, there is always the possibility of common microbial symbionts as the true producers of the isolated substances. This theory will need further investigation.

On the other hand, aspidazide $\mathrm{A}$ is the first natural product isolated directly from a marine invertebrate that has a diacylazide functional group. Although there are several examples of synthetic hydrazides and diacylazides, some of which are in clinical use, only recently has this functional group been detected in natural products. There are only a few examples to date, from a variety of sources, mostly from microorganisms, ${ }^{31-33}$ but also from plant seeds or bulbs. ${ }^{34,35}$ In the marine environment, diacylazides have been isolated from the brown alga Sargassum vachellianum ${ }^{36}$ and from a symbiotic dinoflagellate isolated from a sponge. ${ }^{37}$ These previous reports point toward a possible microbial origin of aspidazide A, another point that will merit further investigation.

Besides the above-mentioned new compounds, the 9-O-ethyl ether of aspidostomide $\mathrm{C}(\mathbf{1 0})$ was also isolated. Compound $\mathbf{1 0}$ had a molecular formula of $\mathrm{C}_{15} \mathrm{H}_{13} \mathrm{Br}_{5} \mathrm{~N}_{2} \mathrm{O}_{3}$, and its mass spectrum also showed a fragment at $\mathrm{m} / \mathrm{z}$ 616.6441, which corresponded to a loss of EtOH. The presence of an ethoxy group was clearly evident in the ${ }^{1} \mathrm{H}$ NMR spectrum by the presence of an extra methylene signal $\left(\delta_{\mathrm{H}} 3.50\right.$ and 3.38$)$ coupled to a methyl group at $\delta_{\mathrm{H}} 1.23$. HMBC correlations of this group with $\mathrm{H}-9$ and C-9 confirmed that compound 10 was the ethyl ether of aspidostomide C. Because $\mathrm{EtOH}$ was used for the extractions, it is highly probable that compound $\mathbf{1 0}$ is an artifact. Three additional compounds were also isolated in this work: 3,4-dibromopyrrole-2-carboxamide, which has been previously isolated from several sponges, 3-bromo-4-methoxybenzoic acid, and methyl-3-bromo-4-methoxybenzoate. ${ }^{38 a, c}$ These compounds are probably biosynthetically related to the aspidostomides or their precursors.
Compounds 1-10 were tested for their cytotoxic activity against the 786-O cell line (human renal carcinoma). The only active compound $\left(\mathrm{IC}_{50}<10 \mu \mathrm{M}\right)$ was aspidostomide $\mathrm{E}(5)$, with an $\mathrm{IC}_{50}$ value of $7.8 \mu \mathrm{M}$. The $\mathrm{IC}_{50}$ values for all compounds are shown in Table S1, Supporting Information.

\section{EXPERIMENTAL SECTION}

General Experimental Procedures. Optical rotations were measured on a PerkinElmer 343 polarimeter. UV spectra were recorded in $\mathrm{MeOH}$ on a Hewlett-Packard 8452 spectrometer. Infrared spectra were obtained (film on $\mathrm{KBr}$ ) on a Nicolet-Magna 550 FT-IR spectrometer. All NMR spectra were recorded in $\left(\mathrm{CD}_{3}\right)_{2} \mathrm{CO}$ or $\mathrm{CDCl}_{3}$ using the signals of residual nondeuterated solvents as internal reference on a Bruker Avance II $500 \mathrm{MHz}$ spectrometer operating at $500.13 \mathrm{MHz}$ for ${ }^{1} \mathrm{H}$ and $125.13 \mathrm{MHz}$ for ${ }^{13} \mathrm{C}$. All 2D NMR experiments (COSY, DEPT-HSQC, HMBC, NOESY) were performed using standard pulse sequences. High-resolution mass spectra were recorded on a Bruker microTOf- $\mathrm{Q}$ instrument. Column chromatography was performed using Merck silica gel 60, 230-400 mesh. Merck silica gel $60 \mathrm{PF}_{254}$ plates were used for preparative TLC. Gel permeation chromatography was performed in $\mathrm{MeOH}$, using Sephadex LH20 (Pharma Inc.). HPLC separations were performed using a Thermo Separations SpectraSeries P100 pump and a Thermo Separations Refractomonitor IV RI detector connected to a Thermo Separations SpectraSeries UV 100 detector, with simultaneous UV $(220 \mathrm{~nm})$ and RI detection. A YMC RP-18 $(5 \mu \mathrm{m}, 20 \mathrm{~mm} \times 250 \mathrm{~mm})$ column working at a flow rate of $5 \mathrm{~mL} / \mathrm{min}$ was used for HPLC separations. All solvents were HPLC grade.

Animal Material. Samples of Aspidostoma giganteum (Busk, 1854) were collected by trawling at a depth of $85 \mathrm{~m}$ during the prawn $P$. muelleri fishing season at the Gulf of San Jorge $\left(45^{\circ} 09^{\prime} \mathrm{S}, 65^{\circ} 35^{\prime} \mathrm{W}\right)$, Patagonia, Argentina, and identified by one of us (C.M). The biological material $(160 \mathrm{~g})$ was frozen on board $\left(-20^{\circ} \mathrm{C}\right)$, transported to the laboratory, and kept frozen until processed. A voucher specimen (MACN-in: 39252) is deposited at the "Bernardino Rivadavia" Museum of Natural Sciences, Buenos Aires, Argentina.

Extraction and Isolation. Frozen samples of A. giganteum (160 g) were triturated and extracted three times with $\mathrm{EtOH}$. The combined extracts were evaporated under reduced pressure to obtain $7.10 \mathrm{~g}$ of a brown syrup. The extract was permeated on Sephadex LH20 $(4 \times 120$ $\mathrm{cm}, \mathrm{MeOH})$, to afford 12 fractions (LH1-LH12). Fraction LH5 (29.0 $\mathrm{mg}$ ) was subjected to HPLC (YMC Rp18, $20 \times 250 \mathrm{~mm}$ ) with $\mathrm{MeOH} / \mathrm{H}_{2} \mathrm{O}$ (65:35), as eluent, yielding compounds 1 (12.0 mg $0.024 \%$ dry wt) and 2 (2.2 mg, 0.0037\% dry wt). Fraction LH6 (63.0 $\mathrm{mg}$ ) was purified by preparative HPLC, employing $\mathrm{MeOH} / \mathrm{H}_{2} \mathrm{O}$ (70:30) as eluent, yielding compounds 3 (3.2 $\mathrm{mg}, 0.0053 \%$ dry wt), 4 (16.0 mg, 0.027\% dry wt), 5 (2.0 mg, 0.0033\% dry wt), and 6 (2.2 mg, $0.0037 \%$ dry wt). Purification of fraction LH7 $(180.7 \mathrm{mg})$ by column chromatography using a cyclohexane/EtOAc/ $\mathrm{MeOH}$ gradient followed by HPLC purification $\left(\mathrm{MeOH} / \mathrm{H}_{2} \mathrm{O}, 1: 1\right)$ afforded compound 9 (23.5 mg, 0.039\% dry wt). Fractions LH8 and LH9 were pooled and subjected to preparative TLC (cyclohexane/EtOAc, 55:45), to yield compound 7 ( $32.1 \mathrm{mg}, 0.054 \%$ dry wt). Finally, fraction LH10 was further fractionated by column chromatography on silica gel, eluting with a cyclohexane/EtOAc gradient, and after final purification by TLC (cyclohexane/EtOAc, 1:1) provided compound $8(2.0 \mathrm{mg}$, $0.0033 \%$ dry wt).

Aspidostomide $A$ (1): amorphous, yellow solid; $[\alpha]^{25}{ }_{\mathrm{D}}-26.5(c$ $0.60, \mathrm{MeOH}) ; \mathrm{UV}(\mathrm{MeOH}) \lambda_{\max }(\log \varepsilon) 255(4.51) \mathrm{nm}$; IR (film $\mathrm{KBr}) \nu_{\max } 3389,2925,1707,1635,1546,1227,1144,736 \mathrm{~cm}^{-1} ;{ }^{1} \mathrm{H}$ and ${ }^{13} \mathrm{C}$ NMR, see Tables 1 and 3; HRESIMS $\mathrm{m} / z$ 556.7332 [M $\mathrm{H}]^{-}$(calcd for $\mathrm{C}_{13} \mathrm{H}_{9}{ }^{79} \mathrm{Br}_{4} \mathrm{~N}_{2} \mathrm{O}_{3}, 556.7352 ; \Delta-2.0 \mathrm{mmu}$ ).

Aspidostomide $B(2)$ : off-white, amorphous solid; $[\alpha]^{25}-28.8$ (c $0.50, \mathrm{MeOH}) ; \mathrm{UV}(\mathrm{MeOH}) \lambda_{\max }(\log \varepsilon) 237(6.43), 273(5.68) \mathrm{nm}$; IR (film KBr) $\nu_{\max } 3403,2967,1726,1635,1553,1227,1201,734$ $\mathrm{cm}^{-1} ;{ }^{1} \mathrm{H}$ and ${ }^{13} \mathrm{C}$ NMR, see Tables 1 and 3; HRESIMS $\mathrm{m} / z 556.7305$ $[\mathrm{M}-\mathrm{H}]^{-}$(calcd for $\mathrm{C}_{13} \mathrm{H}_{9}{ }^{79} \mathrm{Br}_{4} \mathrm{~N}_{2} \mathrm{O}_{3}, 556.7352 ; \Delta 4.7 \mathrm{mmu}$ ).

Aspidostomide C (3): off-white, amorphous solid; $[\alpha]^{25}-31.2(c$ $0.65, \mathrm{MeOH}) ; \mathrm{UV}(\mathrm{MeOH}) \lambda_{\max }(\log \varepsilon) 224(1.97) \mathrm{nm}$; IR (film 
KBr) $\nu_{\max } 3394,2920,1704,1635,1557,1230,1085,736 \mathrm{~cm}^{-1} ;{ }^{1} \mathrm{H}$ and ${ }^{13} \mathrm{C}$ NMR, see Tables 1 and 3; HRESIMS $m / z 634.6463[\mathrm{M} \mathrm{-}$ $\mathrm{H}]^{-}$(calcd for $\mathrm{C}_{13} \mathrm{H}_{8}{ }^{79} \mathrm{Br}_{5} \mathrm{~N}_{2} \mathrm{O}_{3}, 634.6457 ; \Delta-0.6 \mathrm{mmu}$ ).

Aspidostomide D (4): off-white, amorphous solid; $[\alpha]^{25}-2.68(c$ 15.3, MeOH); UV (MeOH) $\lambda_{\max }(\log \varepsilon) 228(0.83) \mathrm{nm}$; IR (film $\mathrm{KBr}) \nu_{\max } 3276,2923,1696,1668,1535,1435,1318,1044,799 \mathrm{~cm}^{-1}$; ${ }^{1} \mathrm{H}$ and ${ }^{13} \mathrm{C}$ NMR, see Tables 2 and 4; HRESIMS $m / z$ 655.6496 [M $\mathrm{H}]^{-}$(calcd for $\mathrm{C}_{15} \mathrm{H}_{7}{ }^{79} \mathrm{Br}_{5} \mathrm{~N}_{3} \mathrm{O}_{2}, 655.6461 ; \Delta-3.5 \mathrm{mmu}$ ).

Aspidostomide $E$ (5): pale yellow, amorphous solid; $[\alpha]_{\mathrm{D}}^{25}-78.0(c$ 1.10, MeOH); UV (MeOH) $\lambda_{\max }(\log \varepsilon) 262(19.8), 293(15.1) \mathrm{nm}$; IR (film KBr) $\nu_{\max } 3409,2923,1674,1527,1432,1318,1080,669$ $\mathrm{cm}^{-1}$; ${ }^{1} \mathrm{H}$ and ${ }^{13} \mathrm{C}$ NMR, see Tables 2 and 4; HRESIMS $\mathrm{m} / z 669.6616$ $[\mathrm{M}-\mathrm{H}]^{-}$(calcd for $\mathrm{C}_{16} \mathrm{H}_{9}{ }^{79} \mathrm{Br}_{5} \mathrm{~N}_{3} \mathrm{O}_{2}, 669.6617 ; \Delta 0.1 \mathrm{mmu}$ ).

Aspidostomide $F$ (6): pale yellow, amorphous solid; UV (MeOH) $\lambda_{\max }(\log \varepsilon) 253(14.5), 293(11.5) \mathrm{nm}$; IR (film KBr) $\nu_{\max } 3284,2912$, 1713, 1646, 1377, $797 \mathrm{~cm}^{-1}$; ${ }^{1} \mathrm{H}$ and ${ }^{13} \mathrm{C}$ NMR, see Tables 2 and 4 HRESIMS $\mathrm{m} / \mathrm{z} 637.6346[\mathrm{M}-\mathrm{H}]^{-}$(calcd for $\mathrm{C}_{15} \mathrm{H}_{5}{ }^{79} \mathrm{Br}_{5} \mathrm{~N}_{3} \mathrm{O}$, 637.6355; $\Delta 0.9 \mathrm{mmu}$ )

Aspidostomide $G$ (7): white, amorphous solid; UV (MeOH) $\lambda_{\max }$ $(\log \varepsilon) 255$ (13.6), $293(12.1) \mathrm{nm}$; IR (film KBr) $\nu_{\max } 3200$, 2928, 1699, 1621, 1568, 1421, 1224, 1086, $677 \mathrm{~cm}^{-1} ;{ }^{1} \mathrm{H}$ and ${ }^{13} \mathrm{C}$ NMR, see Tables 2 and 4; HRESIMS $\mathrm{m} / z$ 579.7494 $[\mathrm{M}-\mathrm{H}]^{-}$(calcd for $\left.\mathrm{C}_{15} \mathrm{H}_{10}{ }^{79} \mathrm{Br}_{4} \mathrm{~N}_{3} \mathrm{O}_{2}, 579.7512 ; \Delta 1.8 \mathrm{mmu}\right)$.

Aspidostomide $H$ (8): white, amorphous solid; $[\alpha]^{25}-25.0(c$ 0.40, $\mathrm{MeOH}$ ); UV (MeOH) $\lambda_{\max }(\log \varepsilon) 228(9.5) \mathrm{nm}$; IR (film KBr) $\nu_{\max } 3733,1643,1546,1394,1116,666 \mathrm{~cm}^{-1} ;{ }^{1} \mathrm{H}$ and ${ }^{13} \mathrm{C}$ NMR, see Tables 1 and 3; HRESIMS $m / z 520.8315[\mathrm{M}-\mathrm{H}]^{-}$(calcd for $\mathrm{C}_{15} \mathrm{H}_{10}{ }^{79} \mathrm{Br}_{3} \mathrm{~N}_{2} \mathrm{O}_{4}, 520.8425 ; \Delta 11.0 \mathrm{mmu}$ ).

Aspidazide A (9): yellow, amorphous solid; UV (MeOH) $\lambda_{\max }(\log$ ع) 295 (12.5) nm; IR (film KBr) $\nu_{\max } 3433,1646,1541,1207,1052$, 872, $669 \mathrm{~cm}^{-1}$; ${ }^{1} \mathrm{H}$ and ${ }^{13} \mathrm{C}$ NMR, see Table 5; HRESIMS $\mathrm{m} / z$ $1072.4232[\mathrm{M}-\mathrm{H}]^{-}\left(\right.$calcd for $\mathrm{C}_{26} \mathrm{H}_{9}{ }^{79} \mathrm{Br}_{8} \mathrm{~N}_{4} \mathrm{O}_{4}, 1072.4180 ; \Delta-0.52$ $\mathrm{mmu})$.

Preparation of MTPA Esters of Compound 1. To a solution of compound $1(1.0 \mathrm{mg}, 1.78 \mu \mathrm{mol})$ in dry pyridine $(300 \mu \mathrm{L})$ was added (R)-MTPA-Cl ( $5 \mu \mathrm{L}, 26.7 \mu \mathrm{mol})$. After $1 \mathrm{~h}$ at $\mathrm{rt}$, the reaction mixture was diluted with EtOAc, extracted three times with $\mathrm{HCl}$, and then washed with $\mathrm{H}_{2} \mathrm{O}$. The organic layer was taken to dryness, and the product was purified by TLC using cyclohexane/EtOAc (6:4) to yield $0.7 \mathrm{mg}$ of the $(S)$-MTPA ester of $\mathbf{1}$. Treatment of $1(1.0 \mathrm{mg})$ with $(S)$ MTPA-Cl in a similar way yielded the corresponding $(R)$-MTPA ester of $1(0.6 \mathrm{mg})$.

(S)-MTPA ester of 1: white, amorphous solid; ${ }^{1} \mathrm{H}$ NMR $\left(\mathrm{CDCl}_{3}\right.$, $500 \mathrm{MHz}) \delta 9.48(\mathrm{bs}, 1 \mathrm{H}) ; 6.98(\mathrm{~d}, J=3.1 \mathrm{~Hz}, 1 \mathrm{H}) ; 6.93(\mathrm{bt}, J=5.6$ $\mathrm{Hz}, 1 \mathrm{H}) ; 3.87,3.72$ (dd, $J=5.6,4.0 \mathrm{~Hz}, 2 \mathrm{H}) ; 7.55(\mathrm{bs}, 2 \mathrm{H})$.

(R)-MTPA ester of 1: white, amorphous solid; ${ }^{1} \mathrm{H}$ NMR $\left(\mathrm{CDCl}_{3}\right.$, $500 \mathrm{MHz}) \delta 9.54(\mathrm{bs}, 1 \mathrm{H}) ; 7.00(\mathrm{~d}, J=3.5 \mathrm{~Hz}, 1 \mathrm{H}) ; 7.07(\mathrm{bt}, J=5.8$ $\mathrm{Hz}, 1 \mathrm{H}) ; 3.90,3.72(\mathrm{dd}, J=5.8,4.0 \mathrm{~Hz}, 2 \mathrm{H}) ; 7.34(\mathrm{~s}, 2 \mathrm{H})$.

Preparation of MTPA Esters of Compound 4. To a solution of compound $4(1.0 \mathrm{mg}, 1.51 \mu \mathrm{mol})$ in dry pyridine $(300 \mu \mathrm{L})$ was added (R)-MTPA-Cl $(0.30 \mu \mathrm{L}, 1.51 \mu \mathrm{mol})$. After $1 \mathrm{~h}$ at $\mathrm{rt}$, the reaction mixture was diluted with EtOAc, extracted three times with $10 \% \mathrm{HCl}$, and then washed with $\mathrm{H}_{2} \mathrm{O}$. The organic layer was taken to dryness, and the product was purified by TLC using cyclohexane/EtOAc (1:1) to yield the $(S)$-MTPA ester of $4(0.7 \mathrm{mg})$. Treatment of $4(1.0 \mathrm{mg})$ with $(S)$-MTPA-Cl in a similar way yielded the corresponding $(R)$ MTPA ester of $4(0.8 \mathrm{mg})$.

(S)-MTPA ester of 4: white, amorphous solid; ${ }^{1} \mathrm{H} \mathrm{NMR}\left(\mathrm{CDCl}_{3}\right.$, $500 \mathrm{MHz}) \delta 6.78(\mathrm{~d}, J=4.5 \mathrm{~Hz}, 1 \mathrm{H}) ; 7.18(\mathrm{~d}, J=8.5 \mathrm{~Hz}, 1 \mathrm{H}) ; 7.29$ (dd, $J=8.5,2.0 \mathrm{~Hz}, 1 \mathrm{H}) ; 7.15$ (bs, $1 \mathrm{H}), \delta 8.40$ (bs, $1 \mathrm{H})$.

(R)-MTPA ester of 4: white, amorphous solid; ${ }^{1} \mathrm{H} \mathrm{NMR}\left(\mathrm{CDCl}_{3}\right.$, $500 \mathrm{MHz}) \delta 6.57(\mathrm{~d}, J=4.5 \mathrm{~Hz}, 1 \mathrm{H}) ; 7.19(\mathrm{~d}, J=9.0 \mathrm{~Hz}, 1 \mathrm{H}) ; 7.30$ (dd, $J=9.0,1.5 \mathrm{~Hz}, 1 \mathrm{H}) ; 7.16$ (bs, $1 \mathrm{H}), \delta 8.40$ (bs, $1 \mathrm{H})$.

Preparation of Compound $\mathbf{4 a}$. $\mathrm{NaH}$ (2 equiv) was added to a solution of $4(1 \mathrm{mg}, 1.51 \mu \mathrm{mol})$ in dry DMSO $(1 \mathrm{~mL})$, and the mixture was stirred at $\mathrm{rt}$ for $20 \mathrm{~min}$ until the solution turned dark green. Then, a solution of $\mathrm{CH}_{3} \mathrm{I}(230 \mu \mathrm{L}, 1.2$ equivs) in DMSO was added dropwise. The reaction was monitored by TLC and was quenched after $1 \mathrm{~h}$. A few drops of $\mathrm{MeOH}$ were added to remove the excess sodium hydride; then $\mathrm{H}_{2} \mathrm{O}$ was added $(5 \mathrm{~mL})$, and the mixture was extracted with EtOAc $(10 \mathrm{~mL} \times 3)$. The organic phase was concentrated and purified by TLC on silica gel, using cyclohexane/ EtOAc (1:1), to yield $7 N, 12 N$-dimethyldehydroaspidostomide D (4a) (0.6 $\mathrm{mg}, 60 \%$ yield).

$7 N, 12 N$-Dimethyldehydroaspidostomide $D(4 a)$ : colorless oil; ${ }^{1} \mathrm{H}$ $\operatorname{NMR}\left(\mathrm{CDCl}_{3}, 500 \mathrm{MHz}\right) \delta 7.49(\mathrm{~d}, J=1.9 \mathrm{~Hz}, 1 \mathrm{H}, \mathrm{H}-17), 7.40(\mathrm{dd}, J$ $=8.7,1.9 \mathrm{~Hz}, 1 \mathrm{H}, \mathrm{H}-15), 7.28(\mathrm{~d}, J=8.7 \mathrm{~Hz}, 1 \mathrm{H}, \mathrm{H}-14), 6.41(\mathrm{~s}, 1 \mathrm{H}$, $\mathrm{H}-8), 3.89$ (s, 3H, N-12 Me), 3.50 (s, 3H, N-7 Me); ${ }^{13} \mathrm{C}$ NMR $\left(\mathrm{CDCl}_{3}, 125 \mathrm{MHz}\right) \delta 154.0$ (C-6), 135.0 (C-13), 131.1 (C-18), 128.8 (C-5), 125.8 (C-15), 123.0 (C-8), 121.2 (C-17), 114.9 (C-16), 111.3 (C-14), 111.0 (C-10), 108.7 (C-2), 105.6 (C-4), 105.2 (C-11), 103.7 (C-9), 98.2 (C-3), $35.0(\mathrm{~N}-7 \mathrm{Me}), 32.3(\mathrm{~N}-12 \mathrm{Me})$; APPI-MS $m / z$ 667.6804 $[\mathrm{M}+\mathrm{H}]^{+}$(calcd for $\mathrm{C}_{17} \mathrm{H}_{11}{ }^{79} \mathrm{Br}_{5} \mathrm{~N}_{3} \mathrm{O}, 667.6814 ; \Delta-0.1$ $\mathrm{mmu})$.

Preparation of Compounds 9a and 9b. To a solution of aspidazide A $(1 \mathrm{mg}, 0.92 \mu \mathrm{mol})$ in dry DMSO $(1 \mathrm{~mL})$ was added 2 equiv of $\mathrm{NaH}$, and the mixture was stirred at $\mathrm{rt}$ for 20 min until the solution turned dark green. Then, a solution of $\mathrm{CH}_{3} \mathrm{I}$ (1.2 equiv) in DMSO was added dropwise. The reaction mixture was then stirred overnight. A few drops of $\mathrm{MeOH}$ were added to remove the excess $\mathrm{NaH}$; then $\mathrm{H}_{2} \mathrm{O}$ was added $(5 \mathrm{~mL})$, and the mixture was extracted with EtOAc. The organic phase was concentrated and purified by TLC on silica gel, using cyclohexane/EtOAc (1:1), after which compounds $9 \mathbf{a}$ and $9 \mathbf{b}$ were obtained in a combined $77 \%$ yield.

Compound 9a: white, amorphous solid; ${ }^{1} \mathrm{H}$ NMR $\left(\mathrm{CD}_{3} \mathrm{COCD}_{3}\right.$, $500 \mathrm{MHz}) \delta 7.83$ (bs, 2H, H-11/H-15), 6.80 (s, 1H, H-8), 6.74 (s, 1H, $\mathrm{H}-2), 3.95$ (s, 3H, O-Me), 3.43 (s, 3H, N-Me); ${ }^{13} \mathrm{C}$ NMR $\left(\mathrm{CD}_{3} \mathrm{COCD}_{3}, 125 \mathrm{MHz}\right) \delta 154.9$ (C-13), $153.8(\mathrm{C}-6), 135.5$ (C11/C-15), 130.1 (C-5), 127.0 (C-9), 122.5 (C-8), 120.2 (C-2), 117.1 (C-10), 109.9 (C-12/C-14), 101.5 (C-4), 95.4 (C-3), 60.4 (O-Me), $33.5(\mathrm{~N}-\mathrm{Me}) ;$ HRESIMS $\mathrm{m} / \mathrm{z} 564.7407[\mathrm{M}-\mathrm{H}]^{-}$(calcd for $\mathrm{C}_{15} \mathrm{H}_{9}{ }^{79} \mathrm{Br}_{4} \mathrm{~N}_{2} \mathrm{O}_{2}, 564.7403 ; \Delta-0.4 \mathrm{mmu}$ ).

Compound 9b: white, amorphous solid; ${ }^{1} \mathrm{H}$ NMR $\left(\mathrm{CD}_{3} \mathrm{COCD}_{3}\right.$, $500 \mathrm{MHz}) \delta 7.85$ (bs, $2 \mathrm{H}, \mathrm{H}-11 / \mathrm{H}-15), 7.24$ (s, 1H, H-4), 6.85 (s, 1H, $\mathrm{H}-8), 3.96$ (s, 3H, O-Me), 3.49 (s, 3H, N-Me); ${ }^{13} \mathrm{C}$ NMR $\left(\mathrm{CD}_{3} \mathrm{COCD}_{3}, 125 \mathrm{MHz}\right) \delta 155.1$ (C-13), 153.5 (C-6), 135.7 (C11/C-15), 129.9 (C-5), 127.1 (C-9), 122.1 (C-8), 117.1 (C-10), 112.3 (C-4), 109.4 (C-12/C-14), 105.9 (C-2), 100.0 (C-3), 60.4 (O-Me), 33.8 ( $\mathrm{N}-\mathrm{Me}$ ); HRESIMS $\mathrm{m} / \mathrm{z} 564.7404[\mathrm{M}-\mathrm{H}]^{-}$(calcd for $\mathrm{C}_{15} \mathrm{H}_{9}{ }^{79} \mathrm{Br}_{4} \mathrm{~N}_{2} \mathrm{O}_{2}, 564.7403 ; \Delta-0.1 \mathrm{mmu}$ ).

Preparation of Compounds $9 \mathrm{c}$ and $9 \mathrm{~d}$. To a solution of aspidazide A $(1 \mathrm{mg}, 0.92 \mu \mathrm{mol})$ in dry DMSO $(1 \mathrm{~mL})$ was added 2 equiv of $\mathrm{NaH}$, and the mixture was stirred at $\mathrm{rt}$ for $30 \mathrm{~min}$ until the solution turned dark green. The reaction was monitored by TLC and was quenched after $30 \mathrm{~min}$. A few drops of $\mathrm{MeOH}$ were added to remove the excess $\mathrm{NaH}$; then $\mathrm{H}_{2} \mathrm{O}$ was added, and the mixture was extracted with EtOAc. The organic phase was concentrated and purified by TLC on silica gel, using cyclohexane/EtOAc (4:6), after which compounds $9 \mathrm{c}$ and $9 \mathrm{~d}$ were obtained in a combined $80 \%$ yield.

Compound 9c: white, amorphous solid; ${ }^{1} \mathrm{H}$ NMR $\left(\mathrm{CD}_{3} \mathrm{COCD}_{3}\right.$, $500 \mathrm{MHz}) \delta 9.81$ (bd, $1 \mathrm{H}, \mathrm{NH}$ amide), $7.73(\mathrm{~s}, 2 \mathrm{H}, \mathrm{H}-11 / \mathrm{H}-15), 6.60$ $(\mathrm{d}, J=5.0 \mathrm{~Hz}, 1 \mathrm{H}, \mathrm{H}-8), 6.72(\mathrm{~s}, 1 \mathrm{H}, \mathrm{H}-2), 5.64(\mathrm{~s}, 1 \mathrm{H}, \mathrm{OH})$; HRESIMS $m / z 535.7062[\mathrm{M}-\mathrm{H}]^{-}\left(\right.$calcd for $\mathrm{C}_{13} \mathrm{H}_{5}{ }^{79} \mathrm{Br}_{4} \mathrm{~N}_{2} \mathrm{O}_{2}$, 564.7090; $\Delta 2.8 \mathrm{mmu}$ ).

Compound 9d: white, amorphous solid; ${ }^{1} \mathrm{H}$ NMR $\left(\mathrm{CD}_{3} \mathrm{COCD}_{3}\right.$, $500 \mathrm{MHz}) \delta 10.0$ (bd, 1H, NH amide), 7.74 (s, 2H, H-11/H-15), 7.25 (s, $1 \mathrm{H}, \mathrm{H}-4), 6.66(\mathrm{~d}, J=5.0 \mathrm{~Hz}, 1 \mathrm{H}, \mathrm{H}-8), 5.64(\mathrm{~s}, 1 \mathrm{H}, \mathrm{OH})$; HRESIMS $m / z 535.7066[\mathrm{M}-\mathrm{H}]^{-}$(calcd for $\mathrm{C}_{13} \mathrm{H}_{5}{ }^{79} \mathrm{Br}_{4} \mathrm{~N}_{2} \mathrm{O}_{2}$, 564.7090; $\Delta 2.4 \mathrm{mmu}$ ).

9-O-Ethylaspidostomide $C(10)$ : yellow, amorphous solid; $[\alpha]^{25}$ 5.8 (c 1.00, MeOH); UV (MeOH) $\lambda_{\max }(\log \varepsilon) 257$ (14.3); IR (film $\mathrm{KBr}) \nu_{\max } 3400,3145,2931,1713,1634,1552,1230,1107,736 \mathrm{~cm}^{-1}$; ${ }^{1} \mathrm{H}$ and ${ }^{13} \mathrm{C}$ NMR, see Tables 1 and 3; HRESIMS $\mathrm{m} / z$ 662.6841 [M $\mathrm{H}]^{-}$(calcd for $\mathrm{C}_{15} \mathrm{H}_{12}{ }^{79} \mathrm{Br}_{5} \mathrm{~N}_{2} \mathrm{O}_{3}, 662.6842 ; \Delta 0.1 \mathrm{mmu}$ ).

Cytotoxicity Evaluation. The effects of the different compounds on cell growth were assayed on log phase unsynchronized monolayers of the 786-O (human clear cell renal cell carcinoma) cell line. The cells were cultured at $37{ }^{\circ} \mathrm{C}$ in plastic flasks in RPMI medium (Gibco; Invitrogen Corp.) in a humidified air atmosphere with $5 \% \mathrm{CO}_{2}$. Serial passages were made by treatment of confluent monolayers with $0.25 \%$ 
trypsin and $0.02 \%$ EDTA in $\mathrm{Ca}^{2+}$ - and $\mathrm{Mg}^{2+}$-free PBS. Cells were periodically determined to be mycoplasma free by Hoechst's method. ${ }^{39}$ The bioassays were carried out as follows: $2 \times 10^{3}$ cells/ well in complete medium were seeded in 96-multiwell plates. After 24 $\mathrm{h}$, the cells received serial doses of the compounds $(0.05-100 \mu \mathrm{M})$ or vehicle (DMSO) in medium plus 2\% FBS (fetal bovine serum) for 3 days. As control, the cytotoxic activity of doxorubicin $\left(\mathrm{IC}_{50}: 0.13 \mu \mathrm{M}\right)$ was also tested. Medium with freshly added compounds was changed every 2 days. Viability was assessed by reduction of the tetrazolium salt (MTS) to the formazan product in viable cells (Cell Titer 96, Promega Corp.) as calculated by the $492 / 620 \mathrm{~nm}$ absorbance ratio. The IC (inhibitory concentration) 50 was defined as the concentration of the compound required for $50 \%$ cell growth inhibition.

\section{ASSOCIATED CONTENT}

\section{S Supporting Information}

Full sets of $1 \mathrm{D}$ and 2D NMR spectra of compounds $1-10 .{ }^{1} \mathrm{H}$ NMR spectra of MTPA esters of compounds 1 and $4 .{ }^{1} \mathrm{H}$ NMR spectra of 3,4-dibromopyrrole-2-carboxamide, 3-bromo-4-methoxybenzoic acid, and methyl-3-bromo-4-methoxybenzoate. Table with $\mathrm{IC}_{50}$ values for all compounds. This material is available free of charge via the Internet at http://pubs.acs.org.

\section{AUTHOR INFORMATION}

\section{Corresponding Author}

*Tel/Fax: 5411-4576-3385. E-mail: palermo@qo.fcen.uba.ar.

\section{Notes}

The authors declare no competing financial interest.

\section{ACKNOWLEDGMENTS}

Research at the University of Buenos Aires was supported by grants from CONICET (PIP 2010-2012 No. 516), UBA (Programation 2014-2017 No. 704), and ANPCyT (PICT 2010 No. 1808). We thank Dr. G. Cabrera (UMYMFORCONICET) for recording the mass spectra and J. Gallardo and G. Eskuche (UMYMFOR-CONICET) for the NMR spectra. L.P. thanks SENACYT-IFARHU (Panamá) for a doctoral fellowship. The authors are grateful to L. Jerez for his help with sample and data collection.

\section{REFERENCES}

(1) Blunt, J. W.; Copp, B. R.; Keyzers, R. A.; Munro, M. H.; Prinsep, M. R. Nat. Prod. Rep. 2013, 30, 237-323 and previous reviews.

(2) Carroll, A. R.; Duffy, S.; Sykes, M.; Avery, V. Org. Biomol. Chem. 2011, 9, 604-609.

(3) Yao, B.; Prinsep, M. R.; Nicholson, B. K.; Gordon, D. P. J. Nat. Prod. 2003, 66, 1074-1077.

(4) Ufe, A.; Chevolot, L.; Larsen, C.; Nielsen, P. H.; Christophersen, C. J. Org. Chem. 1987, 52, 4709-4712.

(5) Zhang, H.; Shigemori, H.; Ishibashi, M.; Kosaka, T.; Pettit, G. R.; Kamano, Y.; Kobayashi, J. Tetrahedron 1994, 50, 10201-10206.

(6) Narkowicz, C. K.; Blackman, A. J.; Lacey, E.; Gill, J. H.; Heiland,

K. J. Nat. Prod. 2002, 65, 938-941.

(7) Morris, B.; Prinsep, M. R. J. Nat. Prod. 1999, 62, 688-693.

(8) Pettit, G. R.; Herald, C. L.; Clardy, J.; Doubek, D. L.; Herald, D. L.; Arnold, E.; Clardy, J. J. Am. Chem. Soc. 1982, 104, 6846-6848.

(9) Carle, J.; Christophersen, C. J. Am. Chem. Soc. 1979, 101, 40124013.

(10) Laycock, M. V.; Wright, J. L. C.; Findlay, J. A.; Patil, A. D. Can. J. Chem. 1986, 64, 1312.

(11) Rochfort, S. J.; Moore, S.; Craft, C.; Martin, N. H.; van Wagoner, R; Wright, J. L.C. J. Nat. Prod. 2009, 72, 1773-1781.

(12) Hara, U. Biogeographical relationship of the South AmericaAntarctic Cenozoic bryozoan biota: The example of austral genus Aspidostoma; USGS Open-File Report, Extended Abstract 214, 2007.
(13) Catalogue of the Marine Polyzoa in the Collection of the British Museum, II. Cheilostomata; Trustees of the British Museum, Natural History: London, 1854; pp 55-120.

(14) Moyano, H. Sci. Mar. 1999, 63, 219-226.

(15) Peng, J.; Li, J.; Hamann, M. T. In The Alkaloids: Chemistry and Biology; Cordell, G. A., Ed.; Elsevier: New York, 2005; Vol. 61, pp 59262.

(16) Silva Lira, N.; Montes, R. C.; Tavares, J. F.; Sobral da Silva, M.; da Cunha, E. V. L; de Athayde-Filho, P. F.; Rodrigues, L. C.; da Silva Dias, C.; Barbosa-Filho, J. M. Mar. Drugs 2011, 9, 2316-2368.

(17) Ohtani, I.; Kusumi, T.; Kashman, Y.; Kakisawa, H. J. Am. Chem. Soc. 1991, 113, 4092-4096.

(18) Pauletti, P. M.; Silva Cintra, L.; Braguine, C. G.; Alves da Silva Filho, A.; Andrade e Silva, M. L.; Cunha, W. R.; Januário, A. H. Mar. Drugs 2010, 8, 1526-1549.

(19) Bertinetti, B.; Scandiani, M.; Cabrera, G. Am. J. Plant Sci. 2011, $245-254$.

(20) Zhang, Y.; Tang, Q.; Luo, M. Org. Biomol. Chem. 2011, 9, 4977-4982.

(21) Gilbert, A.; Cooper, G.; Shade, R. Ind. Eng. Chem. 1959, 51, 665-668.

(22) Krull, L. H.; Friedman, M. Biochem. Biophys. Res. Commun. 1967, 29, 373-377.

(23) (a) Hesek, D.; Lee, M.; Noll, B. C.; Fischer, J. F.; Mobashery, S. J. Org. Chem. 2009, 74, 2567-2570. (b) Mc Conaghy, J. S., Jr.; Bloomfield, J. J. J. Org. Chem. 1968, 33, 3425-3428.

(24) Mancini, I.; Guella, G.; Laboute, P.; Debitus, C.; Pietra, F. J. Chem. Soc., Perkin Trans. 1 1993, 24, 3121-3125.

(25) Cafieri, F.; Fattorusso, E.; Taglialatela-Scafati, O. J. Nat. Prod. 1998, 61, 122-125.

(26) (a) DÁmbrosio, M.; Guerriero, A.; Debitus, C.; Ribes, O.; Pusset, J.; Leroy, S.; Pietra, F. J. Chem. Soc., Chem. Commun. 1993, 1305-1306. (b) Hong, T. W.; Jimenez, D. R.; Molinski, T. F. J. Nat. Prod. 1998, 61, 158-161.

(27) Uemoto, H.; Tsuda, M.; Kobayashi, J. J. Nat. Prod. 1999, 62, $1581-1583$.

(28) Mancini, I.; Guella, G.; Amade, P.; Roussakis, C.; Pietra, F. Tetrahedron Lett. 1997, 38, 6271-6272.

(29) Fattorusso, E.; Taglialatela-Scafati, O. Tetrahedron Lett. 2000, 41, 9917-9922.

(30) Tsuda, M.; Yasuda, T.; Fukushi, E.; Kawabata, J.; Sekiguchi, M.; Fromont, J.; Kobayashi, J. Org. Lett. 2006, 8, 4235-4238.

(31) Ueberschaar, N.; Ndejouong, B. S.; Ding, L.; Maier, A.; Fiebig, H. H.; Hertweck, C. Bioorg. Med. Chem. Lett. 2011, 21, 5839-5841.

(32) (a) Helaly, S. E.; Pesic, A.; Fiedler, H. P.; Süssmuth, R. D. Org. Lett. 2011, 13, 1052-1055. (b) Kim, B. Y.; Willbold, S.; Kulik, A.; Helaly, S. E.; Zinecker, H.; Wiese, J.; Imhoff, J. F.; Goodfellow, M.; Süssmuth, R. D.; Fiedler, H. P. J. Antibiot. 2011, 64, 595-597.

(33) Le Goff, G.; Martin, M. T.; Servy, C.; Cortial, S.; Lopes, P.; Bialecki, A.; Smadja, J.; Ouazzani, J. J. Nat. Prod. 2012, 75, 915-919.

(34) Shoeb, M.; MacManus, S. M.; Jaspars, M.; Trevidu, J.; Nahar, L.; Kong-Thoo-Lin, P.; Sarker, S. D. Tetrahedron 2006, 62, 11172-11177.

(35) Bordoloi, M.; Kotoky, R.; Mahanta, J. J.; Sarma, T. C.; Kanjilal, P. B. Eur. J. Med. Chem. 2009, 44, 2754-2757.

(36) Xu, S. H.; Cen, Y. Z.; Li, Y. L.; Xu, S. Y. Chin. Chem. Lett. 1999, 10, 401-403.

(37) Maru, N.; Ohno, O.; Yamada, K.; Uemura, D. Chem. Lett. 2012, $29,596-597$.

(38) (a) Fouad, M. A.; Debbab, A.; Wray, V.; Muller, W. E. G.; Proksch, P. Tetrahedron 2012, 68, 10176-10179. (b) Ebada, S. S.; Edrada-Ebel, R.; de Voogd, N. J.; Wray, V.; Proksch, P. Nat. Prod. Commun. 2009, 4, 47-52. (c) Hassan, W.; Elkhayat, E. S.; Edrada, R.; Ebel, R.; Proksch, P. Nat. Prod. Commun. 2007, 2, 1149-1154.

(39) Chen, T. R. Exp. Cell Res. 1977, 104, 255-262. 